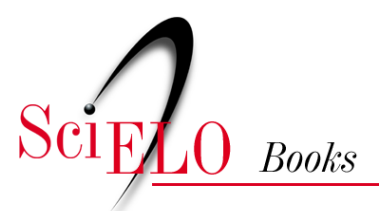

\title{
Questão de Palmas
}

\author{
José Carlos Radin \\ Gentil Corazza
}

\section{SciELO Books / SciELO Livros / SciELO Libros}

RADIN, J.C., and CORAZZA, G. Questão de Palmas. In: Dicionário histórico-social do Oeste catarinense [online]. Chapecó: Editora UFFS, 2018, pp. 135-137. ISBN: 978-85-64905-65-8. https://doi.org/10.7476/9788564905658.0033.

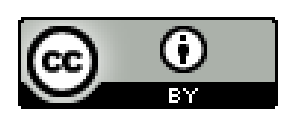

All the contents of this work, except where otherwise noted, is licensed under a Creative Commons Attribution 4.0 International license.

Todo o conteúdo deste trabalho, exceto quando houver ressalva, é publicado sob a licença Creative Commons Atribição $\underline{4.0}$.

Todo el contenido de esta obra, excepto donde se indique lo contrario, está bajo licencia de la licencia $\underline{\text { Creative Commons }}$ Reconocimento 4.0. 


\section{Questão de Palmas}

A Questão de Palmas foi um contencioso fronteiriço entre Brasil e Argentina, ocorrido no final do século XIX. Estava em disputa um território de $30.621 \mathrm{~km}^{2}$ envolvendo, do lado brasileiro, a região Oeste dos estados de Santa Catarina e do Paraná e do lado argentino, a Província de Misiones. Embora as divergências em torno dessa fronteira sejam uma herança que remonta ao período colonial, elas se acentuam, quando a Argentina passa a reivindicar como seu aquele território, com base nos Tratados de Madrid, de 1750, e de Santo Ildefonso, de 1777, que estabeleciam as fronteiras entre Portugal e Espanha. A Questão de Palmas, para os brasileiros, e Question de Misiones, para os argentinos, só veio a ser resolvida através do arbitramento internacional conduzido pelo Presidente dos Estados Unidos, Grover Cleveland, em 1895.

A origem da controvérsia reside no fato de que as fronteiras entre os dois países estabelecidas nos referidos tratados nunca foram efetivamente demarcadas in loco, abrindo, assim, a possibilidade de diferentes interpretações dos acidentes geográficos, como de fato veio a ocorrer. $\mathrm{O}$ Tratado de Madrid foi o primeiro acordo entre Espanha e Portugal sobre os limites respectivos na América do Sul, mas foi o Tratado de Santo Ildefonso que estabeleceu a fronteira entre os dois países na região, no sentido norte-sul, como sendo os rios Peperi-Guaçu e Santo Antônio, mas as comissões demarcadoras, criadas por Portugal e Espanha, nunca chegaram a definir exatamente quais eram esses rios, de modo a evitar futuros litígios de demarcação. A questão agravou-se quando, em 1881, a Argentina entendeu que o rio Peperi-Guaçu do Tratado de 1777 era o atual rio Chapecó, afluente do rio Uruguai e que o rio Santo Antônio, nomeado no mesmo Tratado, era o atual rio Chopim, afluente do rio Iguaçu. Em 1888, uma nova interpretação foi feita pela Argentina, que passou a reivindicar o rio Jangada (também afluente do Iguaçu), como sendo rio Santo Antônio, do Tratado de Santo Ildefonso. A iniciativa unilateral da Argentina ultrapassava os limites fronteiriços anteriores demarcados pelo Tratado de Madri e, com mais precisão, pelo de Santo 
Ildefonso, os quais haviam sido aprovados pelo Congresso da Argentina, em 1857, embora não ratificados pelo governo argentino. Para o Brasil, no entanto, a fronteira entre os dois países devia ser a dos rios Peperi-Guaçu e Santo Antônio, conforme estabelecia o Tratado de Santo Ildefonso. A pretensão argentina acirrou os ânimos e aumentou a tensão na região, pois nenhum dos dois países manifestava disposição de abrir mão daquelas terras. A posição brasileira parecia mais sólida, uma vez que a área contestada, além das populações indígenas, há décadas era habitada quase exclusivamente por brasileiros, não havendo presença de argentinos. Uma vez instalado o litígio, tanto o Brasil como a Argentina fortaleceram suas posições de ambos os lados da fronteira. A Argentina, através da província de Misiones; o Brasil, através das colônias militares de Chapecó e Chopim.

Uma primeira tentativa de acordo ocorreu, em 7 de setembro de 1889, através de um Tratado de Arbitramento, pelo qual o litígio seria resolvido através de arbitragem internacional. No entanto, após a Proclamação da República, em 25 de janeiro de 1890, o Presidente Marechal Deodoro da Fonseca, preocupado com as questões de segurança internas, manifestou disposição em resolver rapidamente a questão dos limites com a Argentina e propôs dividir o território contestado entre os dois países. O acerto foi estabelecido no Acordo de Montevidéu, assinado pelo Ministro das Relações Exteriores do Governo Provisório, Quintino Bacaiuva, mas o Congresso Nacional brasileiro rechaçou esse acordo e reafirmou a vigência do que fora estabelecido no Tratado de Arbitramento.

A Questão de Palmas foi, então, submetida ao presidente dos Estados Unidos, como estabelecia o Tratado de Arbitramento de 1889. Pelo lado do Brasil, atuou inicialmente o barão Aguiar de Andrade, que veio a falecer ainda no desenrolar das negociações. A partir de 1893, coube a José Maria da Silva Paranhos Júnior, barão do Rio Branco, chefiar a delegação brasileira. A delegação argentina foi chefiada por Estanislao Severo Zeballos.

O barão do Rio Branco estava assessorado por uma equipe preparada, da qual fazia parte o general Dionísio Cerqueira. Valendo-se dos seus estudos de história e geografia e da experiência adquirida 
com seu pai, o visconde de Rio Branco, em negociações internacionais anteriores, o barão do Rio Branco valeu-se de um amplo trabalho de reconstituição histórica, geográfica e jurídica, com grande número de mapas e documentos. Apresentou, inclusive, o Mapa das Cortes, de 1749, encontrado no Depósito Geográfico do Ministério dos Negócios Estrangeiros da França, onde se estabelecia com toda a clareza a localização dos rios Peperi-Guaçu e Santo Antônio, que não podiam ser confundidos com os rios Chapecó e Jangada, como pretendia a Argentina. A exposição de Rio Branco representou um verdadeiro tratado geopolítico da região.

Além da farta documentação histórica e geográfica, um dos principais argumentos usados por Rio Branco foi o princípio uti possidetis, segundo o qual tem direito à posse da terra quem a usa. E, no caso em questão, na região reclamada pela Argentina, viviam 5.793 habitantes, dentre os quais 5.763 brasileiros, 30 estrangeiros e nenhum argentino. Além disso, os rios Peperi-guaçu e Santo Antônio estavam mais próximos do território brasileiro do que do argentino e, portanto, as terras do Oeste catarinense e paranaense, reivindicadas pela Argentina, eram de posse histórica de brasileiros, áreas de pecuária, com pequenos núcleos de povoamento, como Palmas do Sul, depois Clevelândia (1838), Palmas (1855), Conceição do Rosário e Campo Erê. Por essas razões, argumentava-se que o território pertencia de fato e de direito ao Brasil.

Em 6 de fevereiro de 1895, o presidente Grover Cleveland emitiu sua sentença, ratificando as pretensões brasileiras. Enquanto Rio Branco era festejado como um herói nacional, o negociador argentino era acusado de incompetente pela imprensa local. A cidade de Clevelândia, no estado do Paraná, localizada na área do litígio, teve o nome dado em homenagem ao presidente norte-americano.

\section{REFERÊNCIAS}

HEINSFELD, Adelar. Fronteira Brasil/Argentina:a questão de Palmas de Alexandre Gusmão a Rio Branco. São Paulo: Méritos, 2007.

ANNIBELLI, Mariana Baggio. Contestado: um território socioambiental. (Dissertação de Mestrado). Curitiba: PUCPR, 2009. 